\title{
New Breast Measurement Technique and Bra Sizing System Based on 3D Body Scan Data
}

\author{
Seolyoung $\mathrm{Oh}^{1}$, Jongsuk Chun ${ }^{2}$ \\ ${ }^{1}$ Apparel Fashion Business, Hansung University, Seoul, 136-792 \\ ${ }^{2}$ Department of Clothing \& Textiles, Yonsei University, Seoul, 120-749
}

\section{Corresponding Author Seolyoung Oh Apparel Fashion Business, Hansung University, 116 Samseongyoro-16gil, Seongbuk-Gu, Seoul, 136-792 \\ Mobile : +82-10-3739-2938 \\ Email : snowbelloh@gmail.com}

Received : April 27, 2014

Revised : June 17, 2014

Accepted: July 02, 2014
Copyright@2014 by Ergonomics Society of Korea. All right reserved.

c. This is an open-access article distributed under the terms of the Creative Commons Attribution Non-Commercial License (http:// creativecommons.org/licenses/by-nc/3.0/), which permits unrestricted non-commercial use, distribution, and reproduction in any medium, provided the original work is properly cited.
Objective: The aim of this study was to develop a method for measuring breast size from three-dimensional (3D) body scan image data.

Background: Previous bra studies established reference points by directly contacting the subject's naked skin to determine the boundary of the breast. But some subjects were uncomfortable with these types of measurements. This study examined noncontact methods of extracting breast reference points from 3D body scan data that were collected while subjects were wearing standardized soft bras.

Method: 3D body scan data of 32 Korean women were analyzed. The subjects were selected from the Size Korea 2010 study. The breast landmarks were identified by graphic analyses of slicing contour lines on 3D body scan data.

Results: Three methods determining bra cup size were compared. The M1 and M2 methods determined cup size by calculating the difference between bust girth and under-bust girth. The M3 method determined bra cup size by measuring breast arc length.

Conclusion: The researchers proposed an anthropometric bra cup sizing system with the breast arc length (M3 method). It was measured from the geometrically defined landmarks on the 3D body scan slicing contour lines. The new bra cup size was highly correlated with breast depth.

Application: The noncontact measuring method used in this study can be applied to the ergonomic studies measuring sensitive body parts.

Keywords: 3D body scan, Bra, Sizing system, Breast arc length

\section{Introduction}

A variety of new technologies are beginning to provide accurate human body measurements and detailed shape information. The application of 3D body scanning has revolutionized anthropometric studies. National anthropometric surveys using 3D body scanning technology have been undertaken in the UK, the USA, Japan, the Netherlands, China, South Africa, Mexico, and France (Bougourd, 2007). National anthropometric surveys in Korean have utilized 3D body scanners since 2005.

There are several problems associated with collecting 3D body scanning data, such as privacy issues, lack of standardization when interpreting measurements, and lack 
of standardized 3D body surface measurement techniques. Al-Mousa (2011) reported that Saudi Arabian women preferred wearing their own clothes during the 3D body scanning process rather than a tightly fitted measuring suit, and another study showed that Korean women preferred to wear their own underwear or street clothes during the 3D body scanning process (Lee et al., 2002).

Measurements of body dimensions with 3D body scanners or by analyzing human figures from 3D body scan data are rapidly evolving. 3D body scan data have been analyzed to identify women's breast sizes and shapes (Kovacs et al., 2007; Wang et al., 2007). Previous studies established physical landmarks by directly contacting the subjects' skin to determine the boundary of the thorax and breast when conducting 3D body scans (Lee et al., 2004, 2007; Lee and Hong, 2006; Zheng et al., 2007; Kim et al., 2010). However, some subjects were uncomfortable with these types of measurements. For this reason, $3 \mathrm{D}$ body scans on female subjects in the Korean national survey were conducted with subjects wearing a standardized soft bra (National Research Foundation of Korea, 2011).

The present study examined methods of extracting breast arc lengths from 3D body scan data that were collected while subjects were wearing standardized soft bras. Breast arc lengths were measured from scanned shape data and used to determine bra cup size.

\section{Review of the literature}

\subsection{D body scanning measurement extraction methods}

The International Organization for Standardization (ISO) has proposed standardized body measurement methods for garment sizing systems (ISO 8559). However, some of the automated body measuring software used with 3D body scanners does not follow ISO standard methods (Han et al., 2006). Sometimes two different scanners measure the same dimension with different landmarks (Paquette et al., 2000). 3D body surface measurements may differ according to body shape (Mckinnon and Istook, 2001).

Previous studies reviewed the compatibility of automated body measurement extraction methods and found that different automated body measurement programs associated with $3 \mathrm{D}$ body scanners defined the same dimensions using different landmarks. For bust girth measurements, the $[T C]^{2} 3 \mathrm{D}$ scanner measured horizontal circumference across bust points at the fullest part of the chest. The Cyberware 3D scanner defined the measurement as the sum of the distances separating successive points from the torso segment that lies on or near a parallel place to the $\mathrm{X}$ axis that passes through the right and left bust points. For the SYMCAD 3D scanner, the "chest girth" (bust measurement) is defined as the horizontal perimeter measured at the average height of the most prominent points of each breast while breathing normally (Simmons and Istook, 2003).

Furthermore, the detailed measurement methods used by automated measurement extraction software according to 3D body scanner type remain obscure, and the accuracy of the data has not been verified. Some software provides body measurement data measured using multiple methods to address this issue. For example, DigiSize ${ }^{\mathrm{TM}}$ software associated with Cyberware 3D scanners provides data obtained by three different body measurement methods: an automatic method (AM, also referred to as the geometry method), a landmark method (LM), and a manual method (MM). The AM analyzes 3D scanned body images and calculates measurements based on normal body form relationships and key physical features. When using the LM, highluminescence markers are placed at specific points on the body before the subject is scanned. The system detects the markers to determine measurement reference locations, and then calculates the specified measurements. In the MM, users identify points on the scanned body surface and distance between each identified point (Cyberware, 1999). 
The 3D body measuring technique proposed in this study is a manual method (MM), which measures the length of a body surface by identifying landmarks on a 3D body scan. We measured breast arc lengths and used these data to devise a new bra cup sizing system.

\subsection{Bra cup size and fit}

Since its advent in the late $19^{\text {th }}$ century, the bra has evolved into a highly complex and sophisticated garment that serves multiple functions by supporting the breasts (Shin, 2010). A well-fitting bra is comfortably snug around the body, with the breasts filling the cups completely. There should not be excess fabric in the cups, nor should breast tissue spill out of the cup at the top, side, or bottom (Elam, 1997).

Even though many studies have focused on good bra fit, the vast majority of women are dissatisfied with the fits of their bras. Hart and Dewsnap (2001) found that most British women had difficulty finding a well-fitting bra. Greenbaum et al. (2003) claimed that very few women wore a bra that matched their breast size. Poorly fitting bras lead to physical discomfort and can cause serious health problems such as muscle fatigue or pain. Producing well-fitting bras has been a challenge to manufacturers and retailers (Wood et al., 2008). Public service agencies and bra companies recommend various methods or formulas to help women select the correct bra size (Chen et al., 2011).

Most poorly fitting bras fit poorly due to incorrect cup size. Bra sizing systems are based on the division of users into groups with similar body measurements. The body dimensions that are used to define groups are called control dimensions or key dimensions. Internationally, bra size is indicated with two key dimensions: bra band size and bra cup size. Bra cup size indicates breast volume size. Most sizing systems define bra cup size as the difference between bust girth and under-bust girth. However, bra cup size does not accurately indicate actual breast volume (Hong, 2002; Park and Lim, 2002).

Bra cup sizes include AA, A, B, C, and so on, up to size E. The difference between bust girth and under-bust girth for an A cup is $10 \mathrm{~cm}$. The difference between bust girth and under-bust girth for a B cup is 1 inch $(2.5 \mathrm{~cm})$ larger than $A$ cup size, or $12.5 \mathrm{~cm}$. Some researchers have proposed a method of classifying bra cup size by breast arc length, as accurate breast arc length measurements might be useful for bra cup sizing and bra design. Pechter (1998) defined bra cup size A as a breast arc length of 7 inches $(17.8 \mathrm{~cm})$. A breast arc length of 8 inches $(20.3 \mathrm{~cm})$ was defined as size B. Every additional inch in breast arc length corresponded to the next bra cup size. Zheng et al. (2007) proposed a different bra cup size system using under-bust girth and breast depth to width ratio. Proper bra fitting begins with an assessment of breast size and shape, and 3D body models are essential for a well-fitting bra design.

\subsection{Measuring breast size}

A well-fitting bra can bring breast tissues back to an attractive position and hold them in place (Wang and Zheng 2007). Breast size must be measured precisely for a good fit.

Many studies have analyzed nude 3D scan data to determine breast shape and size (Lee and Hong 2002, 2007; Chen et al., 2003; Kovacs et al., 2007; Zheng et al., 2007). Several methods have been used to measure breast size and then calculate bra cup size. $[\mathrm{TC}]^{2}$ developed "The New Bust Cup Size Extraction" software program. This is an "open source" expert system developed in conjunction with bra and swimwear manufacturers and the reconstructive medical fields, and is based in the USA. Body landmarks defined by ISO Standards (ISO 8559) and additional measurement points (Pandarum, 2009) are used for measurements.

Park et al. (2004) used breast contour lines to measure breast arc length. The crease line under the breast was defined as the 
inframammary crease line of the breast fatty tissue created by the weight of the breast. This crease is where the breast and the chest meet and is considered the natural bottom boundary of a breast. Some researchers define the inframammary crease line using simple observations of breast shape, while others identify the breast crease line by pulling the breasts in superior, medial, and lateral directions with their palms. The outer crease line of the breast was determined by pulling the breast in the lateral direction, while the inner crease line was determined by pulling the breast in the medial direction (Lee and Hong, 2002). These methods required repeatedly pulling or pushing breast tissue and were uncomfortable for both the subjects and the measurer. In addition, it was difficult to define measuring landmarks because breast tissues tend to sag without support.

Methods of defining breast landmarks using 3D body scan data vary by researcher. Zheng et al. (2007) presented a method for defining positions of inner- and outer- breast point landmarks on the naked body contour slicing line passing the breast point. However, the inner breast point and outer breast point were determined to be significantly lower if the subject had a sagging breast shape (Hong, 2002). To solve this problem, Lee and Hong (2006) suggested measuring the breast while wearing a bra made of thin elastic fabric rather than measuring the nude breast.

Pechter (1998) measured breast arc length with tape from the lateral breast crease to the medial breast crease. Zheng et al. (2007) measured breast girth, depth, and width from scanned nude breast data. Three landmarks, outer-, inner-, and lower-breast points, were marked directly on the skin before scanning the body. They used inner breast point, outer breast point, under breast point, and upper breast point as landmarks for measuring breast volume, but the exact locations of these landmarks are difficult to distinguish (Lee and Hong, 2002). Sophisticated 3D body scan technology has made it possible to construct realistic 3D female breast models (Wang and Zhang, 2007).

In this study, we measured breast arc length and depth using 3D body scan data, with the goal of establishing a technique for measuring breast arc length and depth by defining landmarks on 3D body scan data collected while the subject wore a soft bra. We propose a new bra cup sizing system classified by breast arc length, and compare this new system with the conventional bra cup sizing system.

\section{Method}

\subsection{Processing body scan data}

3D body scan data of Korean women ( $n=32)$ scanned with the Hamamatsu Bodyline Scanner (C 9036-02) (see Figure 1) were analyzed. The subjects were selected from the Size Korea 2010 study. Their under-bust girths ranged from $72.5 \mathrm{~cm}$ to $77.5 \mathrm{~cm}$ and all had symmetrical breast shapes.

The subjects' 3D body scan data were sliced using two crosswise contour slicing lines, L1 and L2. L1 was the bust girth contour slicing line and L2 was the under-bust girth contour slicing line in XZ horizontal direction. L1 crossed the most protruding breast point (PB.P) on the right breast. L2 crossed the least protruding point on the right breast (see Figure 2).

\subsection{Measuring dimensions and measuring points}

Breast arc length, width, and depth measurements were measured as follows: Four breast arc lengths $\left(P_{i}-P_{0}, P_{i}-P_{B . P}, P_{0}-P_{B . P,}\right.$ and $P_{\text {B.P. }}-P_{u}$ ) were measured using $C A D$ (Autodesk AutoCAD ${ }^{\circledR} 2010$ ) (see Figure 3(a) to (c)).

The full breast arc length $\left(P_{i}-P_{o}\right)$ was measured from the inner breast point $\left(P_{i}\right)$ to the outer breast point $\left(P_{o}\right)$ on bust girth slicing line $\left(L_{1}\right)$, and was the sum of the inner breast arc length (@) and the outer breast arc length (b)). The inner breast arc length 


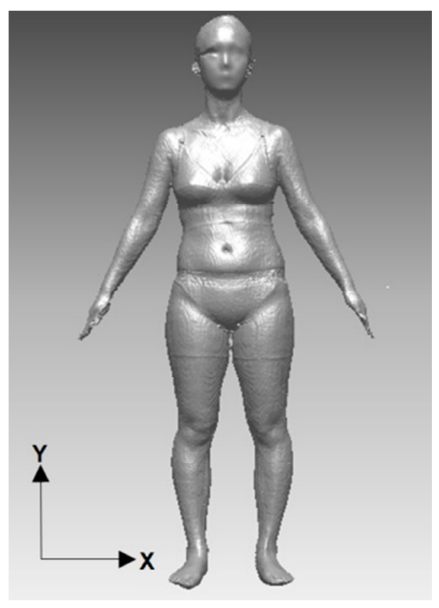

Figure 1. 3D body scan data selected from the Size Korea 2010 study

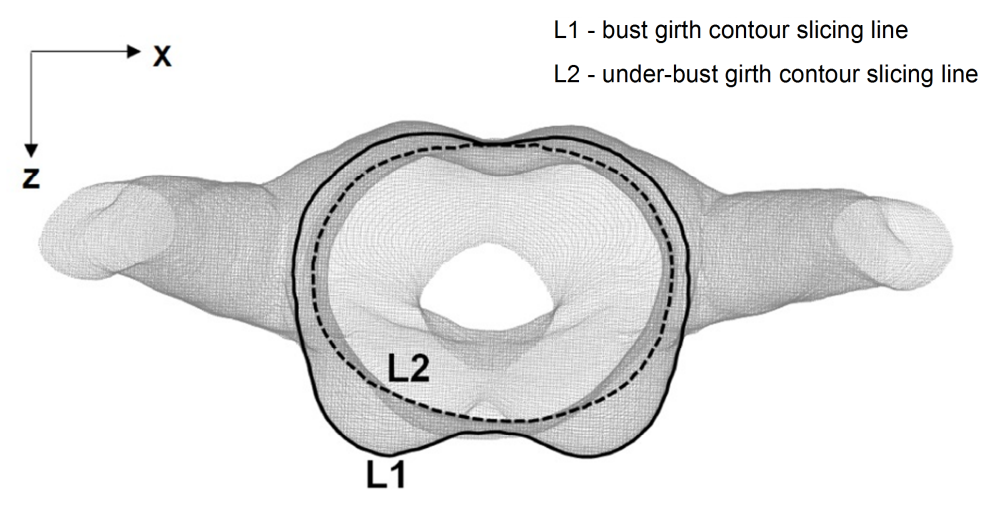

Figure 2. Bust and under-bust slicing contour lines on 3D body scan data

$\left(P_{i}-P_{B . P r}\right.$ (a) was the surface length from the inner breast point $\left(P_{i}\right)$ to breast point $\left(P_{B . P}\right)$. The outer breast arc length $\left(P_{0}-P_{B . P r}\right.$ (b) was the surface length from the outer breast point $\left(P_{o}\right)$ to $P_{B . P .}$. The under-breast arc length $\left(P_{B . P}-P_{u}\right)$ was measured from the breast point $\left(P_{B . P}\right)$ to the under breast point $\left(P_{u}\right)$. The breast point and the under breast point were placed on the breast point slicing line $\left(L_{B . P}\right)$ parallel to the $Y Z$ plane.

The inner breast point $\left(\mathrm{P}_{\mathrm{i}}\right)$ and the outer breast point $\left(\mathrm{P}_{\mathrm{o}}\right)$ were placed on the bust girth contour slicing line $\left(\mathrm{L}_{1}\right)$. The researchers set these breast points $\left(P_{i}\right.$ and $\left.P_{0}\right)$ using the following procedure: First, they selected the upper-bust contour slicing line $L_{3}$ which had the most curving cleavage point among the slicing lines crossing the $X Z$ plane. The inflection point of $L_{3}$ and the center front slicing line $\left(L_{C . F}\right)$ was marked $P_{1}$. $L_{3}$ ran parallel to $L_{1}$ on the $X Z$ plane (see Figure $3(b)$ ). The inner breast point $\left(P_{i}\right)$ was the vertically projected point of $P_{1}$ on line $L_{1}$.

The outer breast point $\left(P_{0}\right)$ was set at the intersection of the bust girth slicing line $\left(L_{1}\right)$ and the cleavage contour slicing line $\left(L_{3}\right)$ on the $X Z$ plane. Point $P_{2}$ on line $L_{3}$ was the projected point of $P_{0}$ on $L_{1}$. Points $P_{2}$ and $P_{0}$ appear to be located in the same place when viewed from above (see Figure $3(a)$ ). 


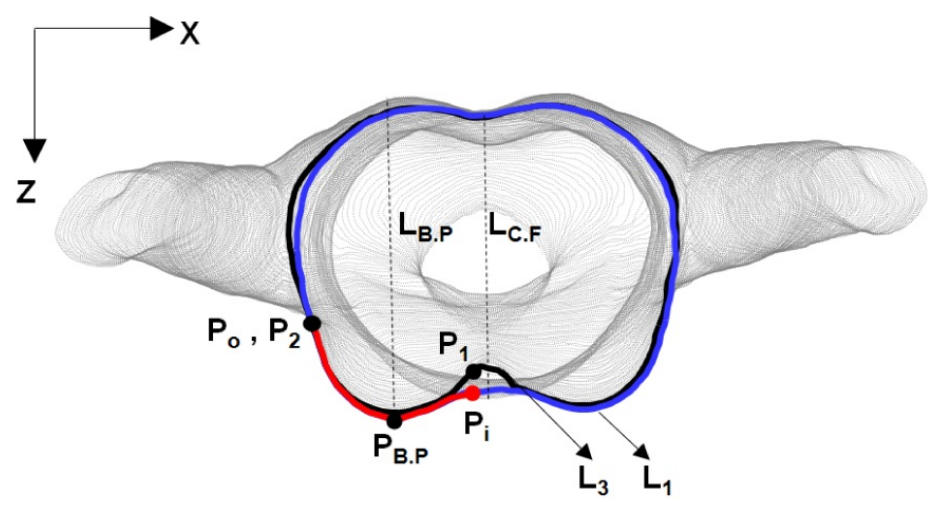
$L_{1}$ : bust girth contour slicing line
$\mathrm{L}_{\text {B.P. }}$ : breast point slicing line
$\mathrm{L}_{2}$ : under-bust girth contour slicing line
$L_{C . F}$ : center front slicing line
$\mathrm{L}_{3}$ : cleavage contour slicing line

Figure 3(a). Breast arc length dimensions - Top view

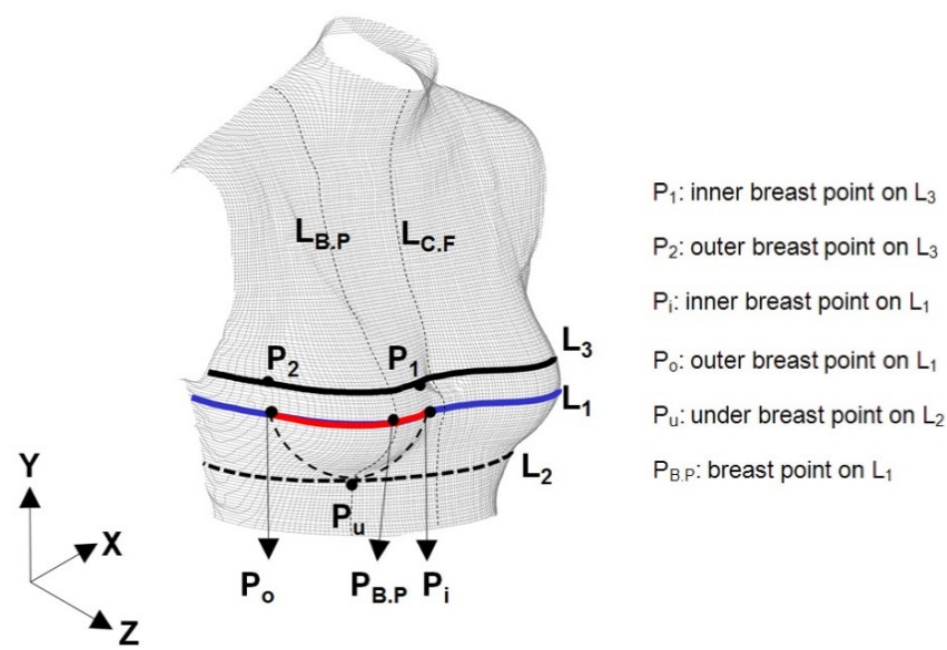

Figure 3(b). Breast arc length dimensions - Side view

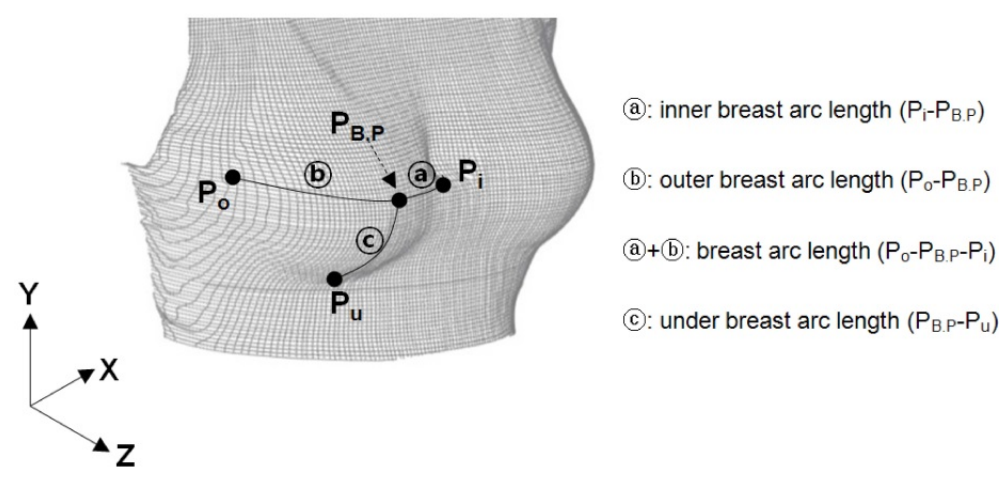

Figure 3(c). Breast arc length dimensions - close up view 
The position of the under-breast point $\left(\mathrm{P}_{\mathrm{u}}\right)$ was the crossing point of the under bust girth slicing line $\left(\mathrm{L}_{2}\right)$ and the breast point slicing line $\left(L_{B . P}\right)$ (see Figure $\left.3(b)\right)$.

Breast width and depth were measured. Breast width $\left(\bigodot_{1}, \overline{\mathrm{P}_{\mathrm{o}} \mathrm{P}_{\mathrm{i}}}\right)$ was defined as the distance from the inner breast point $\left(\mathrm{P}_{\mathrm{i}}\right)$ to the outer breast point $\left(P_{0}\right)$. Breast depth $\left(\overline{P_{\text {B.P.P }} P_{\text {B.P. }}}\right.$, d $)$ was defined as the distance from the breast point $\left(P_{B . P}\right)$ to the line $\overline{P_{0} P_{i}}$ The crossing point on the line $\overline{P_{0} P_{i}}$ was named $P_{B \text {.P. }}$. Breast width (e) was divided into inner breast width $\left(\overline{P_{i} P_{B} . P_{.1}}\right.$ (e)-1) and outer breast width $\left(\overline{P_{\mathrm{O}} P_{\text {B.P.I }}}\right.$, (e)-2). Inner breast width (e-1) was the distance from the inner breast point $\left(P_{i}\right)$ to the crossing point $\left(P_{\text {B.P.I. }}\right)$. Outer breast width (e)-2) was the distance from the outer breast width $\left(P_{0}\right)$ to the crossing point $\left(P_{\text {B.P.I }}\right)$ (see Figure 4).
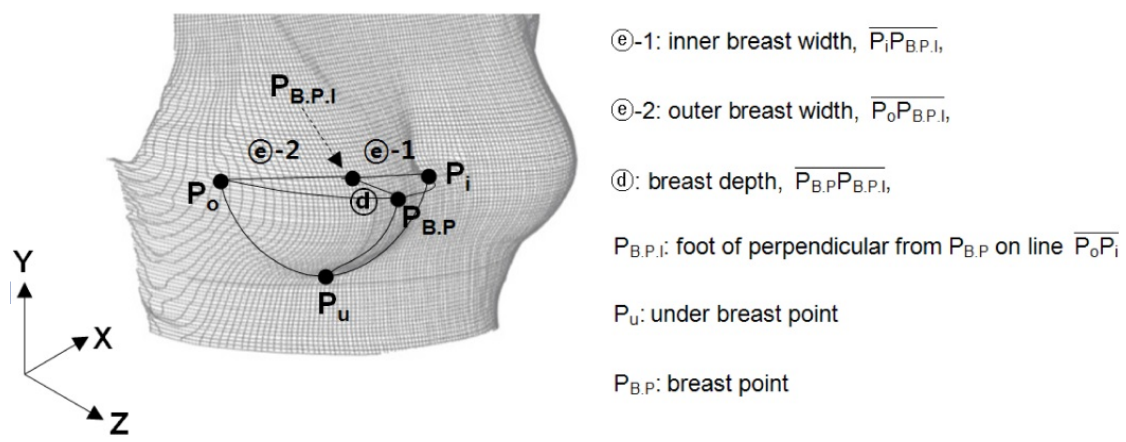

Figure 4. Breast width and depth measurements

\subsection{Comparisons of bra cup size}

Bra cup size was determined using three different methods ( $M 1, M 2$, and $M 3)$. The $M 1$ and $M 2$ methods determined cup size by calculating the difference between bust girth and under-bust girth. The $M 1$ and $M 2$ bra cup sizes were classified into $A A, A$, $B$, and $C$ using the standard Korean bra cup sizing system in KS K 9404:2009. The M3 method determined bra cup size by measuring breast arc length (a)+(b), see Figure $3(c)$ ), and cup size was classified into $A A, A$, , and $C$ using the cup size classification by Pechter (1998).

The M1 method measured bust girth and under-bust girth with a measuring tape. The M2 method measured bust girth at the contour slicing line $\left(\mathrm{L}_{1}\right)$ and under-bust girth at the contour slicing line $\left(\mathrm{L}_{2}\right)$. The difference between the bust girth and underbust girth in the M1 and M2 method was between $6.25-8.75 \mathrm{~cm}$ for AA cups, between $8.75-11.25 \mathrm{~cm}$ for A cups, between $11.26-13.75 \mathrm{~cm}$ for $B$ cups, and between $13.76-16.25 \mathrm{~cm}$ for $C$ cups. For the $M 3$ method, the bra cup size interval was $1.5 \mathrm{~cm}$, with a breast arc length between $14-15.5 \mathrm{~cm}$ for AA cups, $15.5-17 \mathrm{~cm}$ for $A$ cups, $17 \mathrm{~cm}-18.5 \mathrm{~cm}$ for $B$ cups, and between 18.5 $-20 \mathrm{~cm}$ for $C$ cups.

\section{Results}

\subsection{Subject profiles}

Mean bust girth of the 32 subjects, as measured by traditional method according to ISO 8550 , was $86.6 \mathrm{~cm}(\mathrm{SD}=2.68 \mathrm{~cm})$ and 
mean under-bust girth was $75.0 \mathrm{~cm}(\mathrm{SD}=1.60 \mathrm{~cm})$. Average height was $161.6 \mathrm{~cm}(\mathrm{SD}=5.17 \mathrm{~cm})$ and mean body mass index $(\mathrm{BMI})$ was $21.9 \mathrm{~kg} / \mathrm{m}^{2}\left(\mathrm{SD}=1.46 \mathrm{~kg} / \mathrm{m}^{2}\right)$ (see Table 1$)$.

Table 1. Body measurements by traditional method $(\mathrm{N}=32)$

\begin{tabular}{l|c|c}
\hline \multicolumn{1}{c|}{ Dimensions } & Mean & Std. Deviation \\
\hline Bust girth $(\mathrm{cm})$ & 86.6 & 2.68 \\
\hline Under-bust girth $(\mathrm{cm})$ & 75.0 & 1.60 \\
\hline Waist girth $(\mathrm{cm})$ & 70.9 & 2.99 \\
\hline Back waist length (cm) & 38.7 & 1.86 \\
\hline Height $(\mathrm{cm})$ & 161.6 & 5.17 \\
\hline Weight $(\mathrm{kg})$ & 57.3 & 4.29 \\
\hline BMI ${ }^{1)}$ & 21.9 & 1.46 \\
\hline
\end{tabular}

1) BMI (Body Mass Index) = Weight $(\mathrm{kg}) \div$ Height $^{2}\left(\mathrm{~m}^{2}\right)$

Bust girth and under-bust girth as measured by traditional 2D methods according to ISO 8559 (the M1 method) and bust girth and under-bust girth measured by 3D manual method (the M2 method) were compared. The M2 method tends to report larger measurements than the M1 method $(p<0.001, p<0.01)$ (see Table 2).

Table 2. Difference between bust girth and under-bust girth at $M 1$ and $M 2$ methods $(N=32)$

\begin{tabular}{l|c|c|c|c|c}
\hline \multirow{2}{*}{ Dimensions } & \multicolumn{2}{|c|}{$\begin{array}{c}\text { 2D direct measurement } \\
\text { (M1 Method) }\end{array}$} & \multicolumn{2}{c}{$\begin{array}{c}\text { 3D manual measurement } \\
\text { (M2 Method) }\end{array}$} & \multirow{2}{*}{$t$-value } \\
\cline { 2 - 6 } & Mean & SD & Mean & SD & \multirow{2}{*}{$4.253^{\star \star \star}$} \\
\hline Bust girth & 86.55 & 2.680 & 87.84 & 3.308 & $3.215^{\star \star}$ \\
\hline Under-bust girth & 74.97 & 1.599 & 75.74 & 2.156 & \multirow{2}{*}{} \\
\hline
\end{tabular}

When using the M1 method, six subjects were considered bra cup size AA, eight subjects were considered size $A$, nine subjects were considered size $B$, and nine subjects were considered size $C$. When using the $M 3$ method, eight subjects were considered size $A A$, ten subjects were considered size $A$, eight subjects were considered size $B$, and six subjects were considered size $C$

Table 3. Bra cup size distribution of $\mathrm{M} 1$ and $\mathrm{M} 3$ methods $(\mathrm{N}=32)$

\begin{tabular}{|c|c|c|c|c|c|}
\hline M1 bra cup M3 bra cup & AA & $A$ & B & $C$ & Total \\
\hline $\mathrm{AA}$ & $3(50.0 \%)$ & 3 (50.0\%) & $0(0 \%)$ & $0(0 \%)$ & 6 (100\%) \\
\hline$A$ & $4(50.0 \%)$ & 3 (37.5\%) & 1 (12.5\%) & $0(0 \%)$ & 8 (100\%) \\
\hline B & 1 (11.1\%) & 3 (33.30\%) & 3 (33.3\%) & 2 (22.2\%) & 9 (100\%) \\
\hline C & $0(0 \%)$ & 1 (11.1\%) & 4 (44.4\%) & 4 (44.4\%) & 9 (100\%) \\
\hline
\end{tabular}


(see Table 3).

When comparing the M1 vs. M3 methods, $50 \%$ of the subjects considered size AA according to the M1 method were classified as the same size by the $M 3$ method. In addition, $50 \%(n=4)$ of the A cup subjects in the M1 system were classified as size AA in the M3 system and $44.4 \%(n=4)$ of the B cup subjects in the M1 system were classified as size AA or size A in the M3 system. This indicates that the conventional bra cup size sizing system (M1 method) might not accurately reflect breast size.

\subsection{Comparison of breast measurements among bra cup groups}

Breast arc measurements from 3D scan data were analyzed. Breast arc lengths were significantly different among the four $\mathrm{M} 3$ bra cup size groups: AA, A, B, and C. Outer breast arc length (b) was significantly more different among groups than inner breast arc length (a) (see Table 4). The dimensions of (a), (b) and (c) are referenced in Figure 4.

There were no meaningful differences between the AA and A cup size groups for inner breast arc length (a). The inner breast arc length of the $A$ cup size group was slightly shorter than that of the $B$ cup size group $(p<0.005)$. There were more noticeable differences among groups in outer breast arc length (b) $(p<0.001)$. Outer breast arc length of the AA size cup group was significantly shorter than the other groups and outer breast arc length of the $C$ cup size group was the largest of all the size groups. For under breast length (C), there were significant differences between the AA/A size groups and the B/C size groups $(p<0.001)$.

Table 4. Breast arc measurements among M3 bra cup size groups $(\mathrm{N}=32)$

\begin{tabular}{l|c|c|c|c|c}
\hline \multicolumn{1}{c|}{ Dimensions } & $\mathrm{AA}(\mathrm{N}=8)$ & $\mathrm{A}(\mathrm{N}=10)$ & $\mathrm{B}(\mathrm{N}=8)$ & $\mathrm{C}(\mathrm{N}=6)$ & $F$-value \\
\hline Inner breast arc length(@) & $5.86 \mathrm{~A}$ & $5.98 \mathrm{~A}$ & $6.73 \mathrm{~B}$ & $7.02 \mathrm{~B}$ & $6.029^{\star \star}$ \\
\hline Outer breast arc length (b) & $9.16 \mathrm{~A}$ & $10.18 \mathrm{~B}$ & $10.78 \mathrm{~B}$ & $12.62 \mathrm{C}$ & $32.054^{\star \star \star}$ \\
\hline Breast arc length (a)+(b) & $15.02 \mathrm{~A}$ & $16.16 \mathrm{~B}$ & $17.51 \mathrm{C}$ & $19.64 \mathrm{D}$ & $158.483^{\star \star \star}$ \\
\hline Under breast arc length (c) & $5.65 \mathrm{~A}$ & $5.68 \mathrm{~A}$ & $6.60 \mathrm{~B}$ & $7.30 \mathrm{~B}$ & $7.154^{\star \star \star}$ \\
\hline
\end{tabular}

Results from Duncan grouping $\left({ }^{* *} p<.01,{ }^{* \star *} p<.001\right)$ within each bra cup size group. Groups with the same letter were not significantly different.

Breast widths were significantly different among the four M3 bra cup size groups ( $p<.001)$. The dimensions of (d) and (e) are referenced in Figure 4. There were meaningful differences between the AA and A cup size groups, and between the $B$ and $C$ cup size groups $(p<0.001)$, but there was no meaningful difference between the $\mathrm{A}$ and $\mathrm{B}$ cup size groups. Breast width was calculated by joining the inner breast width (e)-1) by the outer breast width (e)-2).

There were noticeable differences in outer breast width between groups (e)-2) $(p<0.001)$, but there were no significant differences in inner breast width (e-1) between groups. This was similar to results for breast arc length in Table 4.

Breast depth as measured by the M3 method differed by bra cup size group $(p<0.001)$ (see Table 5$)$. The results showed that there were meaningful differences in breast depth (d) between the four M3 bra cup size groups, and protrusions of the breast were also different among M3 bra cup size groups $(p<0.001)$. 
Table 5. Breast width and depth measurements among M3 bra cup size groups

\begin{tabular}{l|c|c|c|c|c}
\hline \multicolumn{1}{c|}{ Dimensions } & $\mathrm{AA}(\mathrm{N}=8)$ & $\mathrm{A}(\mathrm{N}=10)$ & $\mathrm{B}(\mathrm{N}=8)$ & $\mathrm{C}(\mathrm{N}=6)$ & $F$-value \\
\hline Breast width (e) & $12.40 \mathrm{~A}$ & $13.36 \mathrm{~B}$ & $13.43 \mathrm{~B}$ & $14.55 \mathrm{C}$ & $25.177^{\star \star \star}$ \\
\hline Inner breast width (e)-1) & 4.74 & 4.47 & 4.56 & 4.35 & 0.553 \\
\hline Outer breast width (e-2) & $7.66 \mathrm{~A}$ & $8.89 \mathrm{~B}$ & $8.88 \mathrm{~B}$ & $10.21 \mathrm{C}$ & $11.329^{\star \star \star}$ \\
\hline Breast depth (@) & $3.26 \mathrm{~A}$ & $3.76 \mathrm{~B}$ & $4.60 \mathrm{C}$ & $5.19 \mathrm{D}$ & $25.748^{\star \star \star}$ \\
\hline
\end{tabular}

Results from Duncan grouping ( $\left.{ }^{* \star} p<.001\right)$ within each bra cup size group. Groups with the same letter were not significantly different.

\section{Conclusion}

Bra cup sizes are defined by breast size. The conventional bra cup sizing system calculates breast size as the difference between bust girth and under-bust girth. However, this method does not result in well-fitting bra cups, and many researchers have attempted to improve bra cup fit. One method that has been used to improve fit is to measure breast size from 3D body scan data. In this study, we used 3D body scan data from Korean national anthropometric surveys during which the subjects wore soft bras made of thin elastic material.

In order to determine breast size, we measured breast arc length separately along the inner- and outer-breast landmarks indicated on 3D body scan data. Those landmarks were identified by analyzing the slicing contour lines of 3D body scan data. One benefit of this method is that we did not need to have direct contact with human subjects, so there was no discomfort on the part of the subjects or researchers during breast measurement. In addition, we proposed a bra cup sizing system based on breast size. There were definite differences among new bra cup size groups in terms of breast arc length, breast width, and breast depth. Measuring breast size in detail illustrated that breast arc length primarily changes around the outer breast. Using the new bra cup sizing system we defined the breast size and it might be useful when making bra because bra cup is estimated using breast arc length, which is a key dimension when making bra cup patterns.

One limitation of this study is that the sample size was small, and that the subjects had bra cup sizes ranging only from 75AA to $75 \mathrm{C}$, so women with larger breasts were not included. Therefore future studies should determine whether the measurement methods and sizing system proposed in this study can be applied to global consumers, including women with breast sizes outside of the range that was included in this study.

\section{References}

Al-Mousa, M., Saudi Arabian consumer's interest in commercial application of 3D body scanner in the apparel market. International Journal of Consumer Studies, 35, 688-694, 2011. doi:10.1111/j.1470-6431.2010.00983

Bougourd, J., Sizing in clothing: Developing effective sizing systems for ready-to-wear clothing. In: S. P. Ashdown, ed. Sizing systems, fit models and target markets. Washington, DC: CRC Press, 108-151, 2007.

Chen, C.M., La Bat, K., and Bye, E., Bust prominence related to bra fit problems. International Journal of Consumer Studies, 35(6), 695-701, 2011. doi:10.1111/j.1470-6431.2010.00984 
Cyberware, Cyberware Digisize Research and Analysis Manual. Monterty, CA: Cyberware, 30-129, 1999.

Elam, C., The Bra Dilemma Solved. Threads, June/July 1997, 36-40, 1997.

Greenbaum, A.R., Heslop, T., Morris, J. and Dunn, K.W., An Investigation of the suitability of Bra Fit in Women Referred for Reduction Mammaplasty. British Journal of Plastic Surgery, 56, 230-236, 2003. doi:10.1016/S0007-1226(03)00122-X

Han, Y.S., Nam, Y.J. and Choi, K.M., The characteristics of 3D Measurements of Korean adult women compared with Manual Measurements. In: D. C. Lee, ed. 2006 Fall Conference and Annual Meeting Ergonomics Society of Korea. 12-13 May 2006 Seoul: Ergonomics Society of Korea, 285-290, 2006.

Hart, C. and Dewsnap, B., An Exploratory Study of the Consumer Decision Process for Intimate Apparel. Journal of Fashion Marketing Management, 5,108-119, 2001. doi:10.1108/EUM0000000007282

Hong, K.H., Engineering Design Process for the Sense-Friendly Comfort Brassiere Using Various Techniques of Human Technology. The Journal of Korean Society of Living Environment System, 9(3), 226-237, 2002.

International Organization for Standardization, 1989. ISO 8559: 1989. Garment Construction and Anthropometric Surveys - Body Dimension.

Kim, Y.W., Kweon, S.A. and Sohn, B.H., Establishment of Brassiere Cup Size and Analysis on Breast Volume. Journal of the Korean Society of Clothing and Textiles, 34(1), 67-77, 2010.

Korean Agency for Technology and Standards, KS K 9404: 2009. Korea sizing systems for foundation garments, 2009.

Kovacs, L., Eder, M., Hollweck, R., Zimmermann, A., Settles, M., Schneiderd, A., Endlicha, M., Muellera, A., Schwenzer-Zimmerere, K., Papadopulosa, N.A. and Biemer, E., Comparison between breast volume measurement using 3D surface imaging and classical techniques. The Breast, 16, 137-145, 2007. doi:10.1016/j.breast.2006.08.001

Lee, H.Y. and Hong, K.H., Fundamental Morphological Consideration for the 3-D Shape Analysis of the Middle-aged Women's Breast. Journal of the Korean Society of Clothing and Textiles, 26(5), 703-714, 2002.

Lee, H.Y., Hong, K.H. and Kim, E.A., Measurement protocol of women's nude breasts using a 3D scanning technique. Applied Ergonomics, 35, 353-359, 2004. doi:10.1016/j.apergo.2004.03.004

Lee, H.Y. and Hong, K.H., Accuracy Improvement of Breast Volume Estimation Using Length Parameters of Breast. The Research Journal of the Costume Culture, 14(5), 840-849, 2006.

Lee, H.Y. and Hong, K.H., Optimal brassiere wire based on the 3D anthropometric measurements of under breast curve. Applied Ergonomics, 38, 377-384, 2007. doi:10.1016/j.apergo.2006.03.014

Lee, S.E., Kunz, G.I., Fiore, A.M. and Campbell, J.R., Acceptance of mass customization in apparel: merchandising issues associated with preference for product, process, and place. Clothing and Textiles Research Journal, 20(3), 138-146, 2002. doi:10.1177/ $0887302 \times 0202000302$ 
McKinnon, L. and Istook, C., Comparative analysis of image twin system and the 3 T6 body scanner. Journal of textile and apparel, Technology and Management, 1(2), 1-7, 2001

National Research Foundation of Korea, Understanding and Practice of Research Ethics. 2011, http://www.cre.or.kr/article/textbook/ 1381813 (retrieved May 10, 2013)

Pandarum, K., Size prediction for plus sized women's intimate appare/ using a 3d body scanner. Thesis (MS). Nelson Mandela Metropolitan University, 2009.

Paquette, Brantley, J.D., Corner, B.D., Li, P. and Oliver, T., Automated extraction of anthropometric data from 3D images. In: 44th Human Factors and Ergonomics Society Annual Meeting, 29 July-4 August 2000 San Diego, CA. Santa Monica, CA: The Human Factors and Ergonomics Society, 727-730, 2000. doi:10.1177/154193120004403811

Park, Y.S. and Lim, Y.J., A Study on Establishment of Brassiere Size and Clothing Pressure for the Twenties-aged Women. Journal of the Korean Society of Costume, 52(8), 15-27, 2002.

Park, Y.S., Kim, S.M., and Kim, E.R., A Study on the Classification of Brassiere Cups by Breast Volume Measurement Values on Women in their Twenties. Journal of the Ergonomics Society of Korea, 23(2), 93-104, 2004.

Pechter, E.A., A new method for determining bra size \& predicting post augmentation breast size. Plastic and Reconstructive Surgery, 102(4), 1259-1265, 1998.

Shin, K., Patternmaking for Underwear Design. United States: CreateSpace. 2-8, 2010.

Simmons, K.P. and Istook, C.L., Body measurement techniques; Comparing 3D body-scanning and anthropometric methods for apparel applications. Journal of Fashion Marketing and Management, 7(3), 306-332, 2003. doi:10.1108/13612020310484852

Wang, J.P. and Zhang, W.Y., 2007. An approach to predicting bra cup dart quantity in the 3D virtual environment. International Journal of clothing science and technology, 19(5), 361-373. doi:10.1108/09556220710819546

Wood, K., Cameron, M. and Fitzgerald, K., Breast size, bra fit and thoracic pain in young women: a correlational study. Chiropractic \& Osteopathy, 16(1), 1-7, 2008. doi:10.1186/1746-1340-16-1

Zheng, R., Yu, W. and Fan, J., Development of a new Chinese bra sizing system based on breast anthropometric measurements. International Journal of Industrial Ergonomics, 37, 697-705, 2007. doi:10.1016/j.ergon.2007.05.008

\section{Author listings}

Seolyoung Oh: snowbelloh@gmail.com

Highest degree: Ph.D., Department of Clothing \& Textiles, Yonsei University

Position title: Full-time Lecturer, Department of Apparel Fashion Business, Hansung University

Areas of interest: 3D Human Body Scanning, Ergonomic Pattern Making 
Jongsuk Chun: jschun@yonsei.ac.kr

Highest degree: Ph.D., Department of Environment, Textiles \& Design, University of Wisconsin-Madison

Position title: Professor, Department of Clothing \& Textiles, School of Human Ecology, Yonsei University

Areas of interest: Functional Clothing Design, Anthropometric Pattern 